\title{
INTERNALISASI ETIKA BERMEDIA SOSIAL NAHDLATUL ULAMA DALAM PENDEKATAN SAINTIFIK
}

\author{
Muh. Ngali Zainal Makmun ${ }^{\text {a) }}$, Masrurotul Mahmudah ${ }^{\text {b) }}$, Muhamad Agus Mushodiq ${ }^{\text {c) }}$
}

a) Institut Agama Islam Ma'arif NU (IAIMNU) Metro Lampung

\section{ABSTRAK}

Penelitian ini bertujuan untuk mengembangkan etika bermedia sosial ala Nahdlatul Ulama (NU) melalui pendekatan saintifik pada Kurikulum 2013. Dewasa ini, begitu banyak informasi hoaks yang tersebar di dunia maya, di mana salah siswa menjadi bagian darinya. Oleh sebab itu, penelitian ini penting dilakukan agar siswa dapat lebih kritis dalam menanggapi informasi yang beredar. Penelitian ini menggunakan pendekatan kualitatif dengan analisis konten sebagai pendekatannya. Adapun temuan penelitian ini adalah internalisasi prinsip tabayun mendorong siswa untuk tidak bersikap apologis dan selalu kritis terhadap informasi yang didapatkan. Selain itu, hal ini mendorong mereka menggali informasi sebanyak-banyaknya sehingga muncul budaya literasi. Prinsip kejujuran dan kebermanfaatan informasi juga mendorong para siswa untuk dapat mengolah informasi dan mengkomunikasikan hasil investigasi secara obyektif. Selain itu, etika menjaga lisan menjadi pijakan bagi siswa untuk menyampaikan pendapat dan informasi yang diperoleh dengan cara yang damai.

\section{ABSTRACT}

This study aims to develop ethics in utilizing social media in the style of Nahdlatul Ulama within Scientific Approach in the 2013 National Curriculum. Currently, hoax massively spreads in cyberspace, in which students become some parts of it. Hence, this research is important so that students are able to be more critical in responding to circulated information. This study employs of qualitative research with content analysis approach. Results show that internalization of tabayun principle encourages students not apological and always critical towards information. In addition, this encourages them to extract information which enhances their literacy. The principle of honesty and the usefulness of information also encourage students to be able to process information and communicate the investigation results objectively. In addition, ethics in verbal communication becomes the foundation for students to deliver information in a peaceful way.

\section{KATA KUNCI}

Pendekatan Saintifik; Nahdlatul Ulama; Tabayun; Hoaks.

\section{KEYWORDS}

Tabayyun; Nahdlatul Ulama; Scientific Approach; Hoax.

\section{A. Pendahuluan}

Di era digital, perkembangan informasi begitu banyak, baik yang bernilai positif maupun negatif. ${ }^{1}$ Setiap manusia mempunyai kebebasan dalam menyampaikan informasi dan hasil pemikirannya. Manusia sebagai pengendali perangkat digital yang bersifat netral bebas nilai; perangkat digital taat dan tunduk pada pengendalinya. Artinya, perangkat digital menyesuaikan jalan

\footnotetext{
${ }^{1}$ Rulli Nasrullah, Media Sosial : Perspektif Komunikasi, Budaya Dan Sosioteknologi (Jakarta: Simbiosa Rekatama Media, 2015), 45. 
M. Ngali Zainal Makmun, Masrurotul Mahmudah, Muhamad Agus Mushodiq

pikir dan kemauan pengendalinya. Wilayah digital di bidang informasi saat ini mengalami perkembangan yang begitu pesat mengalahkan media cetak. Sebuah informasi dengan begitu cepat dapat tersebar ke berbagai kalangan tanpa batas. Maksud dari tanpa batas di sini tanpa mengenal batas usia, kondisi psikologis penerima informasi, penting tidak penting, dan apakah informasi tersebut bernilai positif atau negatif pada penerima informasi. ${ }^{2}$

Pada saat ini siapa saja dapat menjelma layaknya seorang hakim yang dapat menghakimi orang lain. Di sisi lain mereka juga seperti jaksa yang dapat menuntut. Di sisi lain juga dapat membela matimatian layaknya seorang pengacara. Bahkan seseorang seakan-akan bisa menjadi wartawan, komentator, dan ilmuwan di berbagai bidang keilmuan tanpa kejelasan. Sebuah fenomena riil di dunia digital yang sangat bebas. Fenomena tersebut merupakan efek dari pesatnya perkembangan dunia informasi digital, sehingga diperlukan sebuah kode etik dan pengawasan bermedia secara bijak. ${ }^{3}$

Sebuah informasi atau berita dapat disebarkan lewat dunia maya secara mudah oleh seseorang, baik yang otentik ataupun tidak. ${ }^{4}$ Sebuah informasi yang disebarluaskan tersebut sangat mungkin berpotensi menjadi popular, -atau dengan bahasa lain- menjadi viral di jagat maya. Apabila melihat perkembangan informasi yang disebar di dunia maya saat ini, kontennya pun beragam. Sebagian berupa deskripsi peristiwa, kondisi isu-isu sosial politik dan pengalaman pribadi. Sebagian yang lain mengomentari dan menunjukkan keadaan pribadi maupun kondisi masyarakat. Kondisi kelompok-kelompok politik dari kelompok oligarki dan netizen saat ini diperkuat oleh digitalisasi, untuk membentuk kelompok masyarakat yang memiliki pandangan-pandangan berbeda dapat didesain dengan perkembangan yang sedang pesat, sehingga menciptakan hoaks sebagai strategi propaganda.

Media sosial sepertinya sudah menjadi kebutuhan pokok bagi masyarakat Indonesia terutama di kalangan remaja. Remaja dan smartphone sudah menjadi media yang menunjukkan identitas dan jati diri. Media sosial paling sering digunakan oleh remaja seperti Facebook, Twitter, Path, YouTube, Instagram dan BBM. Kondisi yang demikian ini, dikarenakan media sosial memiliki keunggulan dan kemampuan untuk memikat sekaligus menarik bagi penggunanya. Banyaknya kemudahan dan hal-hal menarik yang ditawarkan oleh media sosial memiliki pengaruh yang sangat besar terhadap remaja untuk terus menggunakannnya, akan ada hal yang terasa kurang bagi remaja apabila tidak membawa smartphone. ${ }^{5}$

\footnotetext{
${ }^{2}$ Yuhdi Fahrimal, "Netiquette: Etika Jejaring Sosial Generasi Milenial Dalam Media Sosial," Jurnal Penelitian Pers Dan Komunikasi Pembangunan 22, no. 1 (June 13, 2018): 69-78.

${ }^{3}$ Hadi Suprapto Arifin, "Freedom of Expression di Media Sosial Bagi Remaja Secara Kreatif dan Bertanggung Jawab: Bagi Siswa SMA Al-Ma'soem Rancaekek dan SMA Muhammadiyah Pangandaran," Jurnal Pengabdian Kepada Masyarakat Vol. 1, No. 5 (2017), accessed November 8, 2019, http://jurnal.unpad.ac.id/pkm/article/view/16422.

${ }^{4}$ Feri Sulianta, Keajaiban Sosial Media (Jakarta: Elex Media Komputindo, 2015), 37.

${ }^{5}$ Wilga Secsio Putri, Nunung Nurwati dan Meilanny Budiarti, S, "Pengaruh Media Sosial Terhadap Perilaku Remaja," Prosiding Penelitian dan Pengabdian Kepada Masyarakat Vol. 3, No.1 (2016), accessed November 8, 2019, http://jurnal.unpad.ac.id/prosiding/article/view/13625.
} 
Remaja sangat rentan untuk mempublikasikan berita palsu atau hoaks di dunia maya. ${ }^{6}$ Beberapa kasus yang ditangani oleh polisi adalah kasus penyebaran berita yang bersifat hoaks dilakukan oleh kalangan remaja. Hal tersebut sangat mengkhawatirkan. Menurut Alois Wisnuhardana, remaja mudah termakan isu hoaks dikarenakan secara emosional yang masih labil. Setiap informasi yang masuk, apalagi yang sensasional, langsung disebarkan. Masa remaja merupakan masa dimana seorang manusia memiliki gejolak semangat yang membara. Akan tetapi, mereka seringkali berprinsip tampil beda dengan orang lain untuk menampilkan eksistensi dirinya. ${ }^{7}$

Fenomena media sosial juga berkontribusi pada pembentukan kepribadian remaja. Media sosial memberi kesan buruk bagi perubahan kepribadian, karena remaja dituntut untuk memiliki standar tertentu agar dapat dikatakan mengikuti perkembangan zaman dan mengikuti tokoh tertentu yang sedang viral di media sosial. ${ }^{8}$ Penggunaan media sosial berkembang pesat termasuk di era millennial saat ini. Beberapa di antaranya adalah Instagram, twitter dan Facebook yang kerapkali menampilkan kegaduhan politik dan isu-isu sosial. ${ }^{9}$ Di sisi lain tidak sedikit bentuk kampanye hitam termuat di ketiga platform tersebut. Yang menjadi keresahan bersama kebanyakan masyarakat masih belum mampu memilih dan memilah sumber informasi yang valid dan tidak. Banyak dari masyarakat yang langsung percaya terhadap arus informasi yang dibawa oleh sahabat atau teman terdekat, dibandingkan dengan media yang memiliki validitas kebenaran yang terpercaya.

Dari berbagai berita di dunia maya yang berkembang saat ini, ada yang berimbas negatif maupun positif bagi masyarakat sebagai pembaca secara luas. Bernilai positif apabila informasi yang disampaikan memberikan manfaat dan diperlukan oleh masyarakat. Sebaliknya, akan bernilai negatif dan merugikan secara pribadi dan sosial apabila yang disampaikan berstatus hoaks atau informasi bohong yang dibuat-buat sekedar mencari pemviralan atau memiliki tujuan-tujuan lain yang merugikan berbagai pihak. Terlebih di tahun-tahun politik seperti sekarang ini, banyak beredar beritaberita bohong sehingga membuat keresahan yang memicu konflik di berbagai macam kalangan masyarakat. Aktivitas seperti itu, yakni penyebaran berita hoaks, memberikan dampak berbahaya bagi keharmonisan kehidupan berbangsa dan bernegara.

Media sosial tidak akan lepas dari pengaruh positif atau negatif, pengaruhnya tergantung pada penggunanya sendiri. Karena masa remaja adalah masa transisi untuk menemukan identitas. Namun perhatian terhadap moralitas dan norma dalam pembentukan karakter terhadap para remaja sangatlah penting untuk dilakukan. Kondisi bangsa saat ini bisa menjadi prototipe kondisi bangsa di tahun yang akan datang. Perhatian dan penguatan moralitas dan norma bagi remaja akan sangat

\footnotetext{
${ }^{6}$ EB Surbakti, Kenakalan Orang Tua Penyebab Kenakalan Remaja (Jakarta: Elex Media Komputindo, 2008), 34.

7 Lusia Kus Anna "Remaja Rentan Jadi Penyebar Berita Hoax," Kompas.com, 22 September 2017, diakses 26 Februari 2019, https://lifestyle.kompas.com/read/2017/09/22/161600620/remaja-rentan-jadi-penyebar-berita-hoax.

${ }^{8}$ Surbakti, Kenakalan Orang Tua,.

${ }^{9}$ Eni Maryani, Media dan Perubahan Sosial: Suara Perlawanan Melalui Radio Komunitas, Cet. 1, (Bandung: Remaja Rosdakarya, 2011), 76.
} 
M. Ngali Zainal Makmun, Masrurotul Mahmudah, Muhamad Agus Mushodiq

memberikan efek positip bagi kehidupan bangsa dan negara, remaja kuat dan berkarakter secara otomatis negara akan kuat dan maju.

Yang menjadi permasalahan serius saat ini adalah pada umumnya masyarakat media jarang atau tidak memiliki kemampuan memilih dan memilah berita yang disampaikan istilahnya ditelusuri terhadap sumber informasi. Apabila berita yang didapat tersebut masuk dalam kategori viral, banyak warga media yang langsung mempercayai. Terlebih sumber tersebut ditulis atau dibagikan oleh tokoh yang diidolakan, maka dimungkinkan informasi tersebut langsung dibagikan.

Dalam menyikapi keadaan yang demikian, sangat diperlukan sikap tabayun dan kecerdasan digital yang dikuasai oleh netizen. Kedua hal tersebut diperlukan agar netizen tidak mudah terbawa isu dan berita hoaks (bohong) yang tersebar. Tabayun dan kecerdasan digital perlu disosialisasikan dan diajarkan kepada seluruh lapisan warga masyarakat, terutama dalam wilayah pendidikan. ${ }^{10}$

Lembaga pendidikan menurut hemat penulis merupakan wilayah yang sangat strategis dalam melakukan pembenahan mentalitas dan sikap dalam menghadapi perkembangan media digital yang begitu pesat dan sulit dibendung. Pelajar saat ini sudah sangat familiar dengan perangkat digital. Oleh karena itu, Lembaga pendidikan yang diidentikkan dengan kaum terpelajar sudah saatnya memainkan peran secara akademik memberikan pembelajaran dan pencerahan di dunia digital kepada warga sekolah dan masyarakat secara luas. Untuk itu peneliti mengajukan pertanyaaan penelitian sebagai fokus kajian pada tulisan ini, yaitu bagaimana bentuk internalisasi etika bermedia sosial yang ditetapkan oleh Organisasi Islam Nahdlatul Ulama dalam Pendekatan Saintifik Kurikulum 2013.

Kajian tentang etika bermedia sosial atau komunikasi di media sosial sudah pernah dilakukan oleh Ratna Istriyani dan Nur Huda Widiana dengan judul Etika Komunikasi Islam vs Hoaks di Dunia Maya. Di dalam penelitian tersebut peneliti menyimpulkan bahwa bahaya berita hoaks yang tersebar di dunia maya dapat diminimalisir dengan etika komunikasi yang telah ditetapkan oleh Agama Islam. ${ }^{11}$ Mengingat bahwa prinsip komunikasi Islam diformulasikan berdasarkan roh kedamaian, keramahan, keselamatan yang didasarkan pada pengetahuan yang proporsional bersumber dari Alquran dan Hadis. $^{12}$

Penelitian yang dilakuan oleh kedua peneliti memiliki scope di bidang etika komunikasi Islam sebagai cara alternatif dalam membendung berita hoaks. Kajiannya tidak menyentuh pada ranah pendidikan. Sehingga peneliti mencoba menganalisis etika berkomunikasi dalam media sosial Islam,

\footnotetext{
${ }^{10}$ Kecerdasan digital adalah himpunan kemampuan sosial, emosional dan kognitif yang memungkinkan masyarakat menghadapi tantangan dan beradaptasi dengan tuntutan kehidupan digital. Lihat, Rahma Sugihartati, Perkembangan Masyarakat Informasi \& Teori Sosial Kontemporer (Jakarta: Kencana, 2014).

${ }^{11}$ Ratna Istriyani and Nur Huda Widiana, “Etika Komunikasi Islam vs Hoax Di Dunia Maya," Jurnal Ilmu Dakwah 36, no. 2 (September, 2017), https://doi.org/10.21580/jid.v36.2.1774.

12 Badrudin, Akhlak Tasawuf, (Serang: IAIB PRESS, 2015).
} 
khususnya etika yang dirumuskan dan ditetapkan oleh Nahdlatul Ulama dan diinternalisasi ke dalam Pendekatan Saintifik pada Kurikulum 2013. ${ }^{13}$

Dalam upaya mengembangkan pendekatan saintifik pada Kurikulum 2013 dengan internalisasi etika bermedia sosial Nahdlatul Ulama, peneliti menggunakan jenis penelitian kualitatif-induktif. Induktif di sini mengisyaratkan bahwa peneliti mengolah data dan fenomena yang ada sehingga memunculkan temuan dan teori baru. Pada penelitian ini, peneliti berupaya dalam melakukan internalisasi etika bermedia sosial yang memiliki relasi yang kuat dengan pendekatan saintifik pada Kurikulum 2013. Dalam melakukan analisis data, peneliti melakukan analisis isi terhadap data yang diperoleh, yaitu kode etik bermedia sosial yang disepakati oleh Nahdlatul Ulama dan pendekatan Saintifik yang telah dicanangkan dan ditetapkan oleh pemerintah Republik Indonesia.

\section{B. Membangun Kesadaran Etika Bermedia Sosial Siswa Melalui Pendidikan}

Membangun kesadaran bermedia sosial melalui jalur institusi pedidikan sangat tepat dan efektif. Pada jalur pendidikan, para pelajar dapat dikondisikan dan diarahkan baik melalui sistem pendidikan yang dibuat sekolah maupun pengarahan langsung oleh pendidik. Lembaga pendidikan dalam makna yang luas, memiliki peluang yang besar dalam membangun mentalitas pelajar secara khusus dan masyarakat secara umum, dalam menghadapi gelombang besar perubahan tatanan informasi saat ini. ${ }^{14}$ Dunia saat ini sudah banyak mengalami perubahan yang sangat signifikan dalam berbagai lini kehidupan, termasuk arus informasi media digital yang setiap saat dan secara cepat datang silih berganti dengan berbagai macam motif yang heterogen. ${ }^{15}$

Salah satu yang perlu dibangun dalam pendidikan adalah membangun kesadaran kritis terhadap para pelajar dalam belajar. Membangun kesadaran pelajar agar mampu berfikir kritis merupakan salah satu ciri manusia yang cerdas. Adapun berfikir kritis bisa terwujud apabila dimulai dengan kesadaran kritis yang dibangun melalui jalur pendidikan.

Seorang tokoh pendidikan Paulo Fraire menggolongkan kesadaran manusia menjadi tiga bentuk; yaitu kesadaran magis, naif, dan kritis. Pertama, kesadaran magis adalah suatu bentuk kesadaran yang terbentuk dalam proses belajar mengajar tanpa adanya analisis terhadap suatu masalah, jadi seorang siswa tidak dilatih untuk mengetahui kaitan antara faktor satu dengan faktor yang lain, yang demikian ini menurut Paulo Fraire disebut pendidikan fatalistik. Tidak adanya analisis dapat mengakibatkan pelajar menerima suatu kebenaran secara dogmatis, tanpa adanya mekanisme yang terukur untuk mengetahui dan memahami suatu makna dan idiologi dari setiap konsepsi kehidupan yang ada dalam sosial masyarakat. Kedua, kesadaran naif adalah pada kesadaran ini yang

\footnotetext{
${ }^{13}$ Ridwan Abdullah Sani, Pembelajaran Saintifik untuk Implementasi Kurikulum 2013, ed. oleh Yayat Sri Hayati (Jakarta: Bumi Aksara, 2014), 43 http://digilib.unimed.ac.id/1630/.

${ }^{14}$ Marcel Danesi and A. Gunawan Admiranto, Pengantar Memahami Semiotika Media (Yogyakarta: Jalasutra, 2010), 69.

${ }^{15}$ Sugihartati, Perkembangan Masyarakat Informasi, 47.
} 
M. Ngali Zainal Makmun, Masrurotul Mahmudah, Muhamad Agus Mushodiq

menjadi penyebab akar dari berbagai masalah dimasyarakat dari aspek manusia. Pendidikan dalam masalah ini bertanggung jawab mengarahkan siswa agar mampu beradaptasi dengan struktur dan sistem yang benar dan sudah dibuat, semuanya merupakan sesuatu yang sifatnya "given" tidak perlu dipertanyakan apalagi didebat. Ketiga, kesadaran kritis, kesadaran yang berbanding terbaik dengan kesadaran naif. Kesadaran kritis melihat sistem dan struktur yang dibuat sebagai sumber masalah dalam masyarakat. Paradigma kritis dibangun dalam pendidikan, melatih siswa agar memiliki kemampuan mengidentifikasi ketidakadilan dalam sistim dan struktur, serta mampu menganalisis bagaimana sistem dan struktur bekerja. Menurut Paulo Fraire pendidikan seharusnya tidak terlepas dari realitas manusia dan dirinya. ${ }^{16}$

Dalam pandangan Freire, pendidikan harus kontekstual, artinya memuat terkait realitas sosial yang terjadi di tengah masyarakat. Kontekstualisasi pendidikan merupakan model pendidikan yang mengharuskan siswa untuk menjadi subjek dalam menjawab persoalan-persoalan yang mnggejala dalam realitas sosial masyarakat. Pendidikan dapat mengambil kesadaran sebagai suatu titik tolak yang menampilkan sesuatu yang oleh Freire disebut arkeologi kesadaran. Upaya tersebut bertujuan menguji pemikiran manusia untuk menemukan keadaan sadar. Freire menekankan peran berfikir dalam pembuatan kembali dunia. Penelitian tersebut memungkinkan kesadaran mengambil sikap aktif terhadap dunia. Freire - dengan arkeologi kesadarannya- ingin menemukan kembali sejarah dan kebudayaan. ${ }^{17}$ Berdasarkan pemikiran Freire tersebut, sudah saatnya lembaga pendidikan menampilkan perannya dalam menyambut dan mengawal perubahan di bidang informasi digital. Hal yang demikian perlu segera disikapi dan dilakukang langkah-langkah solutif agar para pelajar tidak terjerumus dalam mengkonsumsi informasi digital yang sulit dipertanggungjawabkan.

Bagi remaja sangat mudah berpeluang dan rentang menjadi subjek pelaku penyebarluasan berita yang bersifat hoaks di dunia virtual. Beberapa pelaku penyebaran berita bohong yang berhasil diamankan pihak kepolisian berstatus sebagai pelajar di sekolah. Menurut Alois Wisnuhardana, Head of Social Media Management Center Kantor Staf Presiden RI, bahwa secara kondisi kejiwaan remaja sangat mudah percaya pada hoaks, hal itu disebabkan anak muda memiliki kecenderungan emosional. Setiap informasi yang didapatkan, terutama yang sifatnya sensasional, akan langsung disebarkan, tanpa berfikir panjang. Data yang dirilis Kementerian Komunikasi dan Informasi Indonesia, faktanya ada 800 ribu situs yang diindikasikan mempopulerkan berita bohong dan kalimat kebencian pada tahun 2016. Hoaks didistribusikan secara luas melalui media sosial. Berdasarkan hasil survei tahun 2017 We Are Social, 18 persen pengguna media sosial usia 13 hingga 17 tahun,yang merupakan usia produktif bagi pelajar. Efek dari berita hoaks sangat berpengaruh bagi remaja dalam kehidupan nyata. Misalnya tindakan kekerasan yang melibatkan kelompok atau penghancuran harga diri seseorang atau

\footnotetext{
${ }^{16}$ Elika Dwi Murwani, "Peran Guru dalam Membangun Kesadaran Kritis Siswa," Jurnal Pendidikan Penabur V, no. 06 (Juni 2006): 60.

${ }^{17}$ Hanik Yuni Alfiyah, "Konsep Pendidikan Imam Zarnuji dan Paulo Freire", Jurnal Pendidikan Agama Islam (Journal of Islamic Education Studies), Vol. 2 No. 2 (2013).
} 
bisa sebuah perusahaan. "Apa saja yang diposting dalam medsos adalah potret masa depan" sebagai remaja seharusnya lebih bijaksana sebelum menyebarkan sebuah berita dan belajar untuk mengklarifikasi berbagai berita atau informasi yang diperoleh dari sosial media. Maka dari itu perlu dilakukan cek kebenarannya dengan membaca sumber beritanya. ${ }^{18}$

Saat ini Indonesia diuji dengan banyak dan mudahnya ujaran kebencian atas nama SARA. Media sosial yang diharapkan menjadi gerakan sosial baru untuk perubahan positif justru menimbulkan hal yang sebaliknya. Media sosial menjadi gerakan tumbuhnya berita hoaks, provokatif, dan ujaran kebencian. Sebagaimana disampaikan oleh Airlangga Pribadi, bahwa pelajar menjadi segmen yang sangat penting pengguna sosial media dengan meluasnya berita yang tidak mampu untuk dipertanggungjawabkan di lingkungan pertemanan dan keluarga. Kondisi yang demikian itu, penting membangun aktor-aktor pelajar yang melek media dan sekaligus kritis terhadap informasi media. $^{19}$

Di sini sedikit kami paparkan beberapa contoh kasus hoaks di sosial media yang melibatkan pelajar, yang diakibatkan salah dalam berkomunikasi di sosial media;

Pertama, peristiwa seorang oknum pelajar berumur 18 tahun berinisial MPA yang menyebarkan informasi palsu yang mengandung unsur propaganda kebencian sehingga pelajar tersebut harus berurusan dengan kepolisian Resor kepolisian Kota Sukabumi. Menurut informasi yang berkembang kejadian tersebut berawal dari aksi pelaku sebagai pemilik akun di medsos Facebook dengan nama Dhegar Stairdi ke sebuah grup media sosial di kota Sukabumi. Pelaku memposting dengan "menyebut kurang lebih 10 ribu orang akan membunuh ulama muslim" informasi ini dikatakan langsung oleh AKBP Susatyo Purnomo sebagai Kapolres Sukabumi Kota menurutnya, berita ini sesat dan menyesatkan.

Kedua, Peristiwa yang mengakibatkan tawuran antar pelajar di Kabupaten Karawang. Kejadian itu bermula dari informasi palsu yang beredar di media sosial bahwa mereka diserang oleh kelompok pelajar yang lain, sehingga berita provokasi tersebut memicu kemarahan dan keonaran dimedia dan realitas, akibatnya mobilisasi pelajar untuk melakukan aksi tawuran antar pelajar tidak terhindarkan untuk melakukan serangan balik. Peristiwa kekerasan tersebut seharusnya tidak terjadi dikalangan pelajar apabila pelajar mampu melakukan komunikasi secara baik di media sosial dengan melakukan klarifikasi dan tidak mudah percaya pada informasi yang tidak jelas beredar di media sosial. Kejadian yang melibat pelajar tersebut disampaikan oleh Bupati Karawang Cellica Nurrachadiana, dalam acara Deklarasi Masyarakat Karawang Anti Hoaks.

\footnotetext{
18 Yasraf Amir Pilliang, "Masyarakat Informasi dan Digital: Teknologi Informasi dan Perubahan Sosial," Jurnal Sosioteknologi 11, no. 27 (December 2012): 143-155.

${ }^{19}$ Airlangga Pribadi, "Kontestasi Ideologi dan Ekonomi Politik Media Era Demokrasi", Jurnal Maarif: Arus Pemikiran Islam dan Sosial, Vol. 13, No. 1 (Juni 2018).
} 
M. Ngali Zainal Makmun, Masrurotul Mahmudah, Muhamad Agus Mushodiq

Sebutan generasi milenial sangat cocok disematkan pada generas saat ini, yang memiliki keahlian dan kemahiran menjelajahi media sosial, sangat berbakat mengunggah foto dan cepat dalam merangkai huruf untuk mengirim pesan dan informasi. Yang menjadi perhatian terkadang mereka tidak tahu tentang bagaimana memilih berita yang akurat dan memercayai setiap berita yang mereka baca.

Penelitian yang dilakukan oleh ilmuan Stanford University pada 2016 lalu menunjukkan bahwa 82 persen siswa sekolah menengah tidak dapat membedakan konten berita iklan dengan berita sesungguhnya di media website. Penelitian yang melibatkan 7.804 pelajar dari sekolah menengah hingga perguruan tinggi tersebut menunjukkan bahwa para pelajar hari ini lebih percaya pada seberapa rinci dan apakah suatu berita melampirkan foto yang sesuai, bukan pada sumber beritanya. Tak ada yang lepas dari berita. Tetapi sebuah studi yang baru dari Project Information Literacy yang dipublikasikan oleh Harvard Graduate School of Education menunjukkan bahwa generasi milenial sebenarnya merasa membutuhkan lebih banyak panduan tentang cara menyeleksi berita yang setiap saat silih berganti mengisi beranda media sosial mereka. Sementara, menurut penelitian the Media Insights Projects, 75 persen dari remaja hari ini kebanyakan menghabiskan waktu untuk online. Penelitian tersebut juga menunjukkan, meski berbagai informasi dapat ditemukan di berbagai sumber di internet, mayoritas mereka cenderung mengambil informasi dari situs media sosial seperti Facebook, Twitter, dan Line. Bahkan, mayoritas generasi milenial lebih memilih mencari berita di media sosial ketimbang membuka laman website media berita. ${ }^{20}$ Semua orang tahu, fokus utama media sosial bukanlah menyajikan berita yang terpercaya. Platform media sosial berfokus menyebarkan informasi secepat dan sebanyak mungkin tanpa memerhatikan kontennya.

Dari berbagai pembahasan dan informasi di atas, tentunya sudah cukup membuktikan bahwa pengaruh media bagi pelajar saat ini sangat besar, sehingga mampu mempengaruhi prilakunya terutama dalam mengkonsumsi dan membagikan berita atau informasi dimedia. Maka sangat diperlukan penyadaran terkait dengan etika bermedia sosial melalui jalur pendidikan. Pendidik harus mampu mengintegrasikan berbagai berita yang sifatnya fenomena dan sensasional bisa dibahas di dalam kelas tentunya dengan menyesuaikan dengan materi pelajaran yang diajarkan. Dengan cara yang demikian tersebut, pelajar akan memiliki kemampuan menganalisis setiap berita yang didapatkan melalui sosial media.

${ }^{20}$ AG Eka Wenats Wuryantai and AG Eka Wenats Wuryantai, "Digitalisasi Masyarakat: Menilik Kekuatan dan Kelemahan Dinamika Era Informasi Digital dan Masyarakat Informasi," Jurnal ILMU KOMUNIKASI 1 (Desember 2004), https://doi.org/10.24002/jik.v1i2.163. 


\section{Internalisasi Etika Bermedia Sosial Nahdlatul Ulama dalam Pendekatan Saintifik Guna Membentengi} Informasi Hoaks bagi Pelajar

Belakangan ini, aktivitas penyebaran berita palsu atau hoaks oleh pegiat media sosial disinyalir banyak dilakukan. Hal tersebut tidak mengherankan karena di era millennial saat ini belum ada kontrol yang pasti dan efisien dalam menangkal berita hoaks, khususnya menangkal pelakunya untuk menyebarkannya. Saat ini, di era publik baru atau new public yang lebih dikenal secara luas dengan istilah netizen memiliki kebebasan dalam men-share postingan atau berita yang diupload oleh pihak tertentu. Netizen yang tidak cerdas dalam menanggapi berita yang diterima, memiliki potensi yang besar dalam menyebarluaskan berita hoaks yang diproduksi oleh pihak-pihak tertentu. Hal tersebut menggambarkan kondisi sosial masyarakat Indonesia bahwa masih banyak di kalangan mereka belum mengetahui akan dampak bahaya berita hoaks. Di sisi lain bagi para penyebar berita hoaks -baik disengaja atau tidak- menggambarkan kurangnya literasi masyarakat sehingga sangat mudah terpengaruh dan percaya apa yang disebarkan oleh pihak tertentu mengenai fenomena sosial, ideologi, dan lain sebagainya.

Salah satu publik baru yang aktif di media sosial adalah para pendidik dan murid baik di sekolah dasar, menengah, atas atau perguruan tinggi. Sebagai akademisi, seyogyanya bagi mereka menjadi agen anti hoaks di dunia maya. Terlebih dengan adanya fakta Era Industri 4.0 sebagai era yang mengunggulkan kemajuan teknologi, khususnya internet maka para akademisi wajib memiliki skill dalam menggunakan perangkat digital dan internet. Skill yang dimaksud adalah dalam menyampaikan pengetahuan yang dikuasai dengan benar dan jujur dan skill dalam memilih berita yang benar dan bermanfaat.

Tulisan ini berusaha membedah substansi Kurikulum 2013 yang masih sangat relevan dengan kondisi pembelajaran saat ini, khususnya terkait dengan penggunaan pendekatan saintifik dalam mensikapi perkembangan kondisi masyarakat dan kaum terpelajar dalam bermedia. Penerapan Kurikululum 2013 membutuhkan perubahan paradigma pembelajaran, yaitu dari pembelajaran konvensional yang hanya dilakukan di kelas yang bersifat tetap dan cenderung tekstual menjadi pembelajaran yang menerobos batasan tekstualitas menuju kontektualisasi yang bersifat nyata. Hal yang demikian itu sangat penting dilakukan agar proses pembelajaran mampu mengaktifkan siswa untuk menggunakan berbagai macam sumber belajar yang diperoleh di luar kelas.

Pendekatan saintifik adalah sebuah terobosan pengelolaan sebuah proses pembelajaran yang diterapkan dalam kurikulum 2013. Ada lima aktivitas belajar yang menjadi pokok perhatian dalam pendekatan saintifik, yakni: aktivitas mengamati, bertanya, melakukan percobaan atau menggali informasi, melakukan penalaran atau asosiasi untuk mengolah informasi dan mengembangkan jaringan atau mengkomunikasikan hasil investigasi. Aktivitas belajar yang demikian sangat-sangat penting dilatih dan dibiasakan oleh para pelajar khususnya, sehingga para pelajar tidak mudah percaya 
M. Ngali Zainal Makmun, Masrurotul Mahmudah, Muhamad Agus Mushodiq

begitu saja pada sebuah informasi pengetahuan tanpa mempelajari dan klarifikasi terlebih dahulu. ${ }^{21}$ Idealnya seorang pelajar itu mampu memberikan pembelajaran yang utuh dan dapat dipertanggungjawabkan secara keilmuan dalam menyebarkan dan menerima sebuah informasi yang beredar dalam dunia digital yang saat ini sudah sangat akrab dengan pelajar dan masyarakat secara umum. Sudah saatnya saat ini dunia pendidikan mampu menerapkan sebuah proses pembelajaran yang mampu mengaktifkan secara positif bagi para pelajar dalam memberikan sumbangsih bagi dunia informasi digital.

Konsep kurikulum K-13, khususnya pada pendekatan saintifik di atas sejatinya memiliki prinsip dan semangat yang sama dengan etika bermedia sosial yang dirumuskan oleh Nahdlatul Ulama. Pengurus Besar Nahdlatul Ulama (PBNU) melalui akun resminya nu.or.id berupaya mendidik publik baru mengenai penangkalan berita hoaks yang tersebar di dunia maya dengan pendapat para ulama klasik dan cendikiawan kontemporer. Nahdlatul Ulama sebagai organisasi sosial keagamaan masyarakat yang besar di Indonesia mengambil langkah untuk mengarahkan para publik baru agar tidak memproduksi atau menyebarkan berita hoaks karena bertentangan dengan ajaran Islam Ahlu asSunnah wal Jama'ah.

Menurut Wasid Mansyur, ada dua hal yang harus diperhatikan oleh publik baru ketika menggunakan sosial media:22 Pertama, adalah perlunya revitalisasi budaya tabayun atau klarifikasi. Banyak sekali publik baru yang menelan mentah-mentah berita yang diterima sehingga dengan mudah membagikan postingan yang didapat di akun media sosialnya. Hal tersebut menunjukkan minimnya budaya literasi masyarakat Indonesia saat ini. Perintah iqra' atau membaca yang sudah digaungkan oleh Alquran sejak lama, jarang dipraktikkan oleh umat Islam saat ini, khususnya masyarakat muslim di Indonesia. Berdasarkan studi yang dilakukan oleh Central Connecticut State University dengan tema "Most Literate Nation in The World" Indonesia menduduki posisi 60 dari 61 negara soal membaca. Hal ini merupakan fakta yang sangat miris sehingga tidak heran jika berita hoaks tersebar di timeline akun media sosial masyarakat Indonesia. Bahkan lebih parah lagi, masyarakat Indonesia sudah mulai kebingungan dalam menentukan mana berita yang benar dan mana berita yang palsu. Dengan penguatan budaya literasi maka horizon pengetahuan masyarakat Indonesia akan meningkat. Dengan hal tersebut budaya klarifikasi terhadap berita yang diterima akan semakin mencuat. Selain minimnya budaya literasi, masyarakat Indonesia juga memiliki sikap fanatik yang cukup tinggi terhadap suatu kelompok. Sikap tersebut menjadikan mereka tidak kritis terhadap informasi yang diterima. Sehingga sikap apologis akan mendorong mereka menerima berita secara apa adanya dan serta merta membagikannya ke ranah publik melalui akun yang dimiliki. Mengingat bahwa menurut Wasid Mansyur -secara penalaran bayani-, penyebaran berita hoaks akan menimbulkan dosa sosial yang

\footnotetext{
${ }^{21}$ Wasid Mansyur, "Media Sosial dan Keadaban Publik," NU Online 22 Januari 2017, accessed February 28, 2019, http://www.nu.or.id/post/read/74800/media-sosial-dan-keadaban-publik.

${ }^{22}$ NU Online, "Media Sosial dan Keadaban Publik."
} 
menciderai kesalahan pribadi seseorang. Selain itu berita hoaks juga merugikan orang lain yang dijadikan objek ujaran kebencian, fitnah, dan prasangka buruk.

Kedua, yang perlu dilakukan oleh publik baru adalah kejujuran dalam menyampaikan berita. Kejujuran -menurut Wasid- merupakan unsur penting yang ada pada Nabi Muhammad yang harus ditanamkan pada diri publik baru. Dengan menanamkan sikap kejujuran pada diri sendiri, maka tidak akan ada berita palsu yang tersebar. Mengingat bahwa sebagaimana yang telah dijelaskan sebelumnya, masyarakat saat ini merasa kebingungan dalam menentukan mana berita yang benar dan palsu. Hal tersebut merupakan akibat dari tersebarnya berita yang tidak jujur. Dengan adanya kejujuran maka para akademisi akan menyampaikan suatu berita, ideologi atau lain sebagainya didasarkan pada kecakapan pengetahuan yang dimiliki tanpa adanya kepentingan lain, khususnya dalam kepentingan politik dan keagamaan. Dengan prinsip objektif, transparan, dan empiris maka berita yang diproduksi oleh pegiat media sosial menambah pengetahuan yang bermanfaat bagi para publik baru atau netizen di media sosial. Dengan kejujuran maka masyarakat memiliki keanekaragaman pengetahuan -yang tidak saling bertentangan- sehingga tidak menjatuhkan salah satu pihak. Artinya dengan keilmuan yang proporsional yang dibagikan oleh cendekiawan atau pegiat media sosial maka akan ada diskusi pengetahuan yang proporsional juga. Mengingat bahwa di era saat ini, khususnya di tahun politik, banyak dari kalangan cendikiawan yang menanggalkan idealisme mereka dalam membagikan ilmu pengetahuan demi sikap pragmatism dalam berpolitik. Selain kejujuran, yang perlu diperhatikan oleh netizen adalah kebermanfaatan. Jika memang apa yang diproduksi oleh para cendekiawan atau pegiat sosial media sudah didasarkan pada kejujuran keilmuan, maka yang harus diperhatikan adalah kebermanfaatan bagi kesatuan bangsa Indonesia sebagai negara dengan semboyan baldatun tayyibatun wa rabbun ghafur. Jika suatu berita diprediksi akan memperkeruh suasana dan memecahbelah persaudaraan antar suku, ras, dan agama, maka seyogyanya berita tersebut tidak disebarkan di publik.

Selain Wasid Mansyur ada juga Rikza Chamami sebagai akademisi di UIN Walisongo Semarang. Dengan mengutip pendapat yang disampaikan oleh KH Sholeh Darat dalam kitabnya Munjiyat pada bab “Madzmumah Kaping Pat Iku Afatul Lisan" Rikza menjelaskan sikap-sikap yang harus dilakukan pegiat media sosial agar terhindar dari berita hoaks. Menurut beliau banyak sekali faktor yang menjadikan seorang hamba terperosok dalam keburukan, salah satunya adalah karena lisannya. Agama Islam sangat tegas dalam memerintahkan umatnya untuk dapat menjaga lisan atau ucapan. Hal tersebut dapat dibuktikan dengan berbagai ayat ataupun hadis mengenai pentingnya menjaga lisan. Salah satu hadis misalnya mengatakan bahwa seorang muslim adalah seseorang yang menyelamatkan dan menentramkan muslim lainnya dari perbuatan tangan dan lisannya. ${ }^{23}$

\footnotetext{
${ }^{23}$ M. Rikza Chamami, "Nasihat KH Sholeh Darat Membendung Hoax," NU Online 11 Januari 2017, accessed February
} 28, 2019, http://www.nu.or.id/post/read/74530/nasihat-kh-sholeh-darat-membendung-hoax. 
Hal tersebut mengindikasikan bahwa lisan memiliki keterkaitan yang sangat erat dengan keharmonisan bermasyarakat. Jika dikontekstualisasi dengan era saat ini, maka pendapat KH Sholeh Darat tidak hanya berkisar tentang lisan saja, tapi juga tulisan. Mengingat bahwa di media sosial, netizen dapat mengekspresikan pendapatnya baik melalui lisan, yaitu dengan video atau rekaman suara dan juga tulisan yang didengar dan dibaca oleh khalayak umum. Adapun sikap yang harus dihindari agar masyarakat dapat menangkal dan menghindari hoaks menurut KH Sholeh Darat ada 20 macam. Sikap sikap tersebut adalah berbicara yang tidak memiliki kebermanfaatan bagi diri sendiri dan orang lain, berlebihan dalam berbicara, ikut serta dalam pembicaraan yang buruk, melakukan perdebatan yang tidak memiliki tujuan yang jelas, bertengkar, melagukan keburukan, mencela, melaknat, tertawa lepas, bernyanyi secara berlebihan, menertawakan orang lain, membuka rahasia orang lain, melakukan perjanjian dan berbicara bohong, melakukan sumpah palsu, melakukan ghibah, adu domba, mempunyai dua lisan (munafik), memuji manusia secara berlebihan, membahas prihal keagamaan tanpa bekal ilmu yang cukup, dan bertanya kepada orang yang tidak concern di bidang keilmuan, khususnya mengenai sifat Allah.

Berdasarkan apa yang telah disampaikan oleh KH Sholeh Darat di atas banyak sekali perilaku yang dilakukan para netizen saat ini. Hal ini merupakan faktor menyebarnya berita hoaks di timeline para pengguna sosial media, baik facebook, twitter, instagram, dan lain sebagainya. Banyak sekali netizen dengan bangga mencela orang atau kelompok tertentu dikemas dengan sebuat tontonan video yang menarik. Betapa banyak para politikus yang menyebarkan janji palsu yang diuatarakan dan dipublikasikan di media sosial sehingga banyak netizen atau publik baru yang merasa dibohongi. Hal tersebutlah yang menjadi bibit akan budaya menyebarkan berita hoaks yang dilakukan para elite dan pejabat Indonesia sebagai role model masyarakat Indonesia. Oleh karena itu, seorang pendidik dan para murid harus menanamkan sikap anti hoaks sebagai agen dalam melawan dan mengikis budaya hoaks pada masyarakat Indonesia secara umum.

Berdasarkan pemaparan dua tokoh di atas, dapat disimpulkan bahwa lima aktivitas belajar yang menjadi pokok perhatian dalam pendekatan saintifik, yakni: aktivitas mengamati, bertanya, melakukan percobaan atau menggali informasi, melakukan penalaran atau asosiasi untuk mengolah informasi dan mengembangkan jaringan atau mengkomunikasikan hasil investigasi memiliki prinsip yang sama dengan etika bermedia sosial Nahdlatul Ulama. Sikap tabayun yang dikembangkan oleh Nahdlatul Ulama mendorong para pegiat media sosial untuk selalu kritis, mengamati fenomena yang sesungguhnya, dan melakukan penalaran dengan akal yang sehat. Sikap kejujuran dalam bermedia sosial juga mendorong pegiat media sosial untuk selalu menggali informasi, melakukan share terhadap suatu informasi yang didasarkan pada kejujuran ilmu pengetahuan yang dikuasai.

Selain itu apa yang disampaikan oleh Rikza dengan mengutip pendapat KH Sholeh Darat bahwa dalam menggunakan lisan atau tulisan, pelajar secara umum harus memperhatikan berbagai hal, khususnya dalam menerapkan pendekatan saintifik. Perdebatan dan diskusi di dalam penerapan 
pendekatan saintifik misalnya. Harus diterapkan dengan bahasa dan strategi yang terstruktur. Sehingga diskusi memiliki tujuan yang jelas. Diskusi tidak gersang tanpa tujuan apapun. Dalam aktivitas penalaran, juga diperlukan kiat-kiat yang telah disampaikan oleh KH Sholeh Darat seperti tidak menertawakan orang lain, membuka rahasia orang lain, melakukan perjanjian dan berbicara bohong, melakukan sumpah palsu, dan membahas prihal keagamaan dan ilmu pengetahuan ilmiah tanpa bekal ilmu yang cukup.

Sekali lagi, penting untuk diperhatikan bahwa pendekatan saintifik merupakan sebuah aktivitas pembelajaran. Sebuah proses yang didesain agar peserta didik atau pelajar memiliki kemampuan untuk melakukan rekonsturksi konsep berfikir, memiliki kemampuan identifikasi masalah, mampu meyampaikan masalah dan merumuskan secara baik sebuah hipotesis. Dalam pendekatan saintifik pelajar juga dibekali dengan kemampuan untuk memahami aneka teknik dalam mengumpukan data sekaligus bisa menganalisa data yang didapat untuk selanjutnya dapat menarik sebuah kesimpulan dengan menghubungkan konsep dan hukum yang ditemukan. Dengan kemampuan merekonstruksi tersebut seorang pelajar pada akhirnya akan mampu menarik sebuah kesimpulan informasi yang tepat dari berbagai masalah yang berkembang diwilayah sosial masyarakat. Masyarakat saat ini memerlukan sebuah bimbingan terutama dalam mengidentifikasi dan menganalisis banyaknya informasi yang beredar didunia digital yang belum pernah terjadi sebelumnya. Harapannya dari penerapan pendekatan saintifik tersebut dalam proses pembelajaran akan mampu memaksimalkan peran pelajar yang lebih luas kepada masyarakat, agar mampu meminimalisir kesimpulan yang salah dalam menerima informasi pengetahuan di zona digital.

Berdasarkan kajian ilmiah dari guru besar bahwa proses pembelajaran tradisional dan kontekstual memiliki selisih hasil yang jauh berbeda. Tradisional di sini diartikan bahwa seorang murit hanya dibiasakan menerima sebuah informasi pengetahuan tanpa diarahkan dan dibiasakan berfikir secara kritis terhadap sebuah informasi pengetahuan yang didapat, tentunya akan berbeada dengan pembelajaran yang bersifat kontektual yang mengajak pelajar untuk aktif berfikir dalam menggali berbagai informasi pengetahuan, baik itu dari teks maupun konteks dalam proses pembelajaran. Hal ini diperkuat dengan hasil retensi informasi guru besar pada sistem tradisional hanya 10 persen setelah 15 menit dan pemahaman kontekstual sebesar 25 persen, sedangkan pada pembelajaran berbasis pendekatan ilmiah dalam hal ini melalui pendekatan saintifik resistensi informasi dari guru besar sebesar 90 persen dan tingkat pemahamannya kontektualnya sebesar 50-70 persen. Maksud dari Pendekatan saintifik adalah memberikan kesadaran pada peserta didik tentang aktivitas untuk mengenal, memahami dari berbagai materi yang diajarkan, informasinya tidak terbatas dari sekolah dan guru, informasi bisa didapat dari mana saja. Kondisi yang demikian ini yang memperkuat pendapat penulis khususnya bahwa penerapan pendekatan saintifik sangat perlu dilakukan dalam sebuah proses pembelajaran, mengingat dampak positifnya terhadap hasil belajar para pelajar. Yang demikian itu 
M. Ngali Zainal Makmun, Masrurotul Mahmudah, Muhamad Agus Mushodiq

memang tidak mudah perlu konsistensi pembiasaan dan kenginginan yang kuat dari berbagai pihak, terutama dewan guru yang bersinggungan langsung dengan para pelajar.

Secara umum dapat dipahami bahwa tujuan dari adanya aktivitas belajar mengajar dalam kurikulum 2013 yang berdasarkan pada taksonomi tujuan pendidikan adalah pengaktifan tiga ranah, yaitu ranah kognitif, ranah afektif, dan ranah psikomotor. ${ }^{24}$ Ketiga ranah ini secara simultan diperhatikan secara berimbang jangan berat sebelah terlalu mementingkan salah satu ranah. Maksudnya dalam proses pembelajaran seorang pendidik sudah seharusnya mampu mengarahkan siswa didiknya memiliki tiga kecerdasan ketiga ranah tersebut, sehingga hasil pendidikan lebih meningkat baik secara intelektualitas dan sikap dari para pelajar. Sebagaimana tercantum dalam Undang- Undang Nomor 20 Tahun 2003 yang berbicara tentang Sistem Pendidikan Nasional, taksonomi tersebut diadopsi dalam bentuk rumusan sikap, pengetahuan, dan keterampilan. Undang-Undang tersebut menjadi landasan yang penting bagi sistem pendidikan kita saat ini, bahwa seharusnya intelektualitas terhubung langsung dengan bentuk prilaku seorang pelajar dalam kehidupan sehingga dapat menjadi teladan bagi masyarakat secara lebih luas. ${ }^{25}$

Penerapan berbagai langkah pembelajaran saintifik tersebut, secara langsung atau tidak langsung akan memberikan pengaruh besar bagi pelajar negeri ini terhadap pengalaman dan pengetahuan kepada peserta didik, yaitu tentang bagaimana para peserta didik melakukan tabayun atau check and re-check terhadap segala pengetahuan dan informasi berita yang didapat.

\section{Kesimpulan}

Berdasarkan pemaparan di atas, peneliti menyimpulkan bahwa etika bermedia sosial yang dirumuskan oleh Nahdlatul Ulama (NU), yaitu sikap tabayun (klarifikasi), kejujuran dan kebermanfaatan informasi merupakan aspek-aspek yang harus diinternalisasi pada pendekatan saintifik Kurikulum 2013. Dengan adanya tabayun maka siswa memiliki dorongan untuk tidak bersikap apologis dan selalu kritis terhadap informasi yang didapatkan. Selain itu, sikap tabayun yang ditanamkan pada diri siswa mendorong mereka menggali informasi sebanyak-banyaknya. Sehingga budaya literasi pada siswa selalu berkembang. Sikap kejujuran dan kebermanfaatan informasi juga medorong para siswa untuk dapat mengolah informasi dan mengkomunikasikan hasil invesitagasi dengan asas kebenaran dan objektif. Di sisi lain, etika dalam menjaga lisan juga menjadi fondasi dasar bagi para siswa untuk menyampaikan pendapat dan informasi yang diperoleh, seperti sikap tidak berdiskusi dan berdebat yang tidak meiliki ujung dan tidak menyampaikan kebohongan mengenai informasi tertentu.

\footnotetext{
24 Rudi Susilana, "Pendekatan Saintifik dalam Implementasi Kurikulum 2013 Berdasarkan Kajian Teori Psikologi Belajar," EDUTECH 13, no. 2 (August 2014): 183, https://doi.org/10.17509/edutech.v13i2.3095.

${ }^{25}$ Sani, Pembelajaran Saintifik.
} 


\section{E. Referensi}

Admiranto, Marcel Danesi and A. Gunawan. Pengantar Memahami Semiotika Media. Yogyakarta: Jalasutra, 2010.

Alfiyah, Hanik Yuni. "Konsep Pendidikan Imam Zarnuji dan Paulo Freire." Jurnal Pendidikan Agama Islam (Journal of Islamic Education Studies), 2013.

Anna, Lusia Kus. Kompas.com. September 2017. https://lifestyle.kompas.com/read/2017/09/22/161600620/remaja-rentan-jadi-penyebarberita-hoax (accessed Februari 26, 2019).

Arifin, Hadi Suprapto. "Freedom of Expression di Media Sosial Bagi Remaja Secara Kreatif dan Bertanggung Jawab: Bagi Siswa SMA Al-Ma'soem Rancaekek dan SMA Muhammadiyah Pangandaran." Jurnal Pengabdian Kepada Masyarakat, 2017.

Badrudin. Akhlak Tasawuf. Serang: IAIB PRESS, 2015.

Chamami, M. Rikza. NU Online. Januari 11, 2017. http://www.nu.or.id/post/read/74530/nasihat-khsholeh-darat-membendung-hoax. (accessed February 28, 2019).

Fahrimal, Yuhdi. "Netiquette: Etika Jejaring Sosial Generasi Milenial Dalam Media Sosial." Jurnal Penelitian Pers Dan Komunikasi Pembangunan, 2018: 69-78.

Mansyur, Wasid. NU Online. Januari 22, 2017. http://www.nu.or.id/post/read/74800/media-sosialdan-keadaban-publik. (accessed February 28, 2019).

Maryani, Eni. Media dan Perubahan Sosial: Suara Perlawanan Melalui Radio Komunitas. Bandung: Remaja Rosdakarya, 2011.

Murwani, Elika Dwi. "Peran Guru dalam Membangun Kesadaran Kritis Siswa." Jurnal Pendidikan Penabur, 2006: 60.

Nasrullah, Rulli. Media Sosial: Perspektif Komunikasi, Budaya dan Sosioteknologi. Jakarta: Simbiosa Rekatama Media, 2015.

Pilliang, Yasraf Amir. "Masyarakat Informasi dan Digital: Teknologi Informasi dan Perubahan Sosial." Jurnal Sosioteknologi, 2012: 143-155.

Pribadi, Airlangga. "Kontestasi Ideologi dan Ekonomi Politik Media Era Demokrasi." Jurnal Maarif: Arus Pemikiran Islam dan Sosial, 2018.

Sani, Ridwan Abdullah. Pembelajaran Saintifik untuk Implementasi Kurikulum 2013. Jakarta: Bumi Aksara, 2014.

Sugihartati, Rahma. Perkembangan Masyarakat Informasi \& Teori Sosial Kontemporer. Jakarta: Kencana, 2014.

Sulianta, Feri. Keajaiban Sosial Media. Jakarta: Elex Media Komputindo, 2015.

Surbakti, EB. Kenakalan Orang Tua Penyebab Kenakalan Remaja. Jakarta: Elex Media Komputindo, 2008.

Susilana, Rudi. "Pendekatan Saintifik dalam Implementasi Kurikulum 2013 Berdasarkan Kajian Teori Psikologi Belajar." EDUTECH, 2014: 183.

Widiana, Ratna Istriyani and Nur Huda. "Etika Komunikasi Islam Vs Hoax Di Dunia Maya." Jurnal IImu Dakwah, 2017.

Wilga Secsio Putri, Nunung Nurwati dan Meilanny Budiarti, S. "Pengaruh Media Sosial Terhadap Perilaku Remaja." Prosiding Penelitian dan Pengabdian Kepada Masyarakat, 2016.

Wuryantai, AG Eka Wenats Wuryantai and AG Eka Wenats. "Digitalisasi Masyarakat: Menilik Kekuatan dan Kelemahan Dinamika Era Informasi Digital dan Masyarakat Informasi." Jurnal ILMU KOMUNIKASI, 2004. 
M. Ngali Zainal Makmun, Masrurotul Mahmudah, Muhamad Agus Mushodiq 